\title{
EFFECT OF DIETARY OLIVE LEAVES AND CHAMOMILE FLOWERS POWDER ON THE GROWTH PERFORMANCE AND CARCASS TRAITS AND OF BROILERS (SASSO BREED)
}

\author{
HALA Y.A. NASSAR ${ }^{1}$; HASSAN A.M. ABDEL-RAHEEM ${ }^{2}$ and SOTOHY A. SOTOHY ${ }^{3}$ \\ ${ }^{1}$ Animal \& Clinical Nutrition Dept., Fac. of Vet. Med., New Valley University, Egypt \\ ${ }^{2}$ Animal \& Clinical Nutrition Dept., Fac. of Vet. Med., Assiut Univ., Assiut, Egypt. \\ ${ }^{3}$ Animal Hygiene Dept. Fac. of Vet. Med., Assiut University, Assiut, Egypt
}

Received: 30 September 2019; Accepted: 24 October 2019

\begin{abstract}
The current work was conducted to evaluate the effect of feeding Olive leaves and chamomile flowers powders either single or in combination on growth performance, carcass traits, serum parameters and immune response of Sasso broilers. A total number of 126 one-day old unsexed Sasso chicks (average weight $35 \mathrm{~g}$ ) were obtained from local commercial source and randomly distributed into 6 equal groups each of 21 chicks (7 chicks/replicate). In the first group, birds were fed ad-libitum on starter, grower and finisher basal control diets, while chicks in the second and third groups fed on diets supplemented with $1 \& 2 \%$ olive leaves powder (OLP). Birds in the fourth and fifth groups fed diets containing $0.75 \& 1 \%$ chamomile flowers powder, while broilers in the sixth group fed on diet supplemented with $2 \%$ olive leaves powder $+1 \%$ chamomile flowers powder. Control basal starter, grower and finisher diets were formulated according to guidelines of Sasso breed requirements. Birds were fed according to three phases program (starter, grower and finisher) for 70 days experimental period. Growth performance, carcass traits, serum biochemical and immune parameters were assessed. The results showed that, olive leaves powder supplemented groups (groups 2,3), chamomile flower powder supplemented group (group 4) and birds in the sixth group (group 6) recorded higher body weight gain $(1277.67 \pm 33.42 \mathrm{~g}$, $1375.75 \pm 46.07 \mathrm{~g}, 1277.17 \pm 50.30$ and $1267.25 \pm 37.12 \mathrm{~g})$, respectively and best feed conversion $(2.17,2.03$, 2.17 and 2.11$)$ than that recorded by control group $(1221.50 \pm 47.29 \mathrm{~g} \& 2.26)$. Addition of olive leaves powder, chamomile flower powder or their combination to broiler diets had no significant effect $(\mathrm{p}<0.05)$ on dressing percentage or the relative weights of internal organ compared with the control group. Total serum protein and globulin were significantly increased, while albumin/globulin ratio was significantly decreased in the third group compared with control one. There were significant decreases in serum cholesterol levels in all treatment groups except fourth group, while there was significantly decrease in triglycerides level in sixth group in comparison with other groups and control group. Serum levels of malondialdehyde (MDA) were significantly decreased in the second, third and fourth groups, while there were no significant differences were observed in fifth and sixth groups. Serum catalase enzyme was significantly increased in the third and fourth groups compared with treated groups and control. WBCs counts and lymphocytes \% were significantly increased in all treated groups except the third group which show no significant effect. The relative weights of bursa were significantly increased in all treated groups compared with control. There were significantly increased in the relative weight of thymus in third and fifth groups, while the relative weight of spleen significantly increased in fifth and sixth groups comparison with control. Results of the current study concluded that, the best growth performance and immune response were observed in broilers of the third group fed diet containing $2 \%$ olive leaves powder.
\end{abstract}

Key words: Growth performance, carcass traits, broilers, Sasso breed

\section{INTRODUCTION}

Phytogenic feed additives have received attention as possible replacements for antibiotic growth promoters (Huyghebaert et al., 2011).

Corresponding author: HALA Y.A. NASSAR

E-mail address: halavet63@yahoo.com

Present address: Animal \& Clinical Nutrition Dept., Fac. of Vet. Med., New Valley University, Egypt.
Moreover, aromatic plants and their components in animal nutrition are potential to beneficially influence appetite and daily feed intake of broilers. Herbs and herbal products are incorporated in livestock feeds instead of chemical products in order to stimulate or promote the effective use of feed nutrients which result in more rapid gain, higher production and better feed efficiency (Ghazalah and Ali, 2008). Today, many studies focus on using of natural feed additives in poultry diets as antioxidant 
(Florou-Paneri et al., 2006) or antimicrobial (Botsoglou et al., 2010). Olive leaves are agricultural residues from the beating of olive trees (Oleaeuropea L.) for fruit harvest. Olive leaves contain many important substances as oleuropein, tyrosol and hydroxytyrosol (Silva et al., 2006). Olive leaves have several pharmacological properties as immune-stimulator, antibacterial (Bisignano et al., 2001), antifungal, anti-viral (Fredrickson, 2000), anti-inflammatory and antibacterial activities (Korukluoglu et al., 2010) and antioxidant properties (Mujić et al., 2011; Hamad, 2015). The addition of olive leaves to broiler diets resulted in a significant increase in weight gain and improved feed conversion (Fayed $e t$ al., 2009; Erener et al., 2009 and Lee-Huang et al., 2011). El-Damarawy et al. (2013) observed that olive leaves powder supplementation at the level of $2.0 \%$ to Mandarah chick diets improved performance and most of immunological and biochemical traits. El-damrawy (2011) found that olive leaves extract was effective in minimizing the oxidative stress which was induced with the advance of thiobarbituric acid reactive substances (TBARS), superoxide dismutase (SOD) and glutathione stransferase (GST). Amino acids, polysaccharides, fatty acids, essential oils, mineral elements, flavonoids and other phenolic compounds are the main constituents of chamomile. Chamomile shows different pharmacological activities like antibacterial, antifungal, antiviral and strong antioxidant properties (Al Bahtiti, 2012). Improvement in body weight gain and feed conversion of broilers fed chamomile flowers powder were reported by Galib et al. (2011) and Mahmoud (2013). Abaza et al. (2003) suggested that addition of $2.5 \mathrm{~g} / \mathrm{kg}$ chamomile flower powder to broiler diet improved growth performance. The current work was conducted to evaluate the effect of feeding olive leaves powder and chamomile flowers either single or in combination on growth performance, carcass traits, blood biochemical parameters and immune response of Sasso broilers.

\section{MATERIALS AND METHODS}

The current work was carried out at the Teaching Veterinary Hospital, Department of Animal Nutrition and Clinical Nutrition, Faculty of Veterinary Medicine, Assuit University (March May 2019).

\section{Experimental chicks and housing:}

126 one- day old unsexed Sasso chicks (average weight $35 \mathrm{~g}$ ) were obtained from local commercial source, weighed and randomly distributed into 6 equal groups each of 21 chicks (7 chicks/replicate). The experimental room was previously disinfected with Cid 20 and floor area bedded with a layer of chaffed wood. The experimental pens were equipped with cylindrical plastic feeders, water founts, thermostatically controlled heaters and ventilation fans to maintain room temperature and air flow. Birds were kept under the same managerial system and environmental conditions. Broilers were vaccinated against New Castle viral disease and Infectious bursal disease via eye drops. Hygienic disposal of organic wastes was followed.

\section{Experimental design:}

Sasso chicks were experimented to study the effect of feeding olive leaves and chamomile flowers powder either single or in combination on growth performance, carcass traits, some blood biochemical parameters and immune response. Experimental design was shown in Table 1.

Table 1: The applied experimental design of the current work.

\begin{tabular}{cccc}
\hline Treatments & Groups & Diets & Added level \\
\hline T1 & 1 & control & - \\
\hline T2 & 2 & olive leaves powder & $1 \%$ \\
\hline T3 & 3 & olive leaves powder & $2 \%$ \\
\hline T4 & 4 & chamomile flowers powder & $0.75 \%$ \\
\hline T5 & 5 & chamomile flowers powder & $1 \%$ \\
\hline T6 & 6 & olive leaves + chamomile flowers & $2 \%+1 \%$ \\
\hline
\end{tabular}

\section{Diets and feeding:}

The standard basal control starter, grower and finisher diets were formulated in a mash form (yellow corn, soybean meal, corn gluten and sunflower oil) according to guidelines of Sasso breed requirements. In the first group, birds were fed ad-libitum on starter, grower and finisher basal control diets, while chicks in the second and third groups fed on the same diets supplemented with $1 \&$ $2 \%$ olive leaves powder. Birds in the fourth and fifth groups fed diets containing $0.75 \& 1 \%$ chamomile flowers powder while, broilers in the sixth group fed on diet supplemented with $2 \%$ olive leaves powder + $1 \%$ chamomile flowers powder. Birds were fed 
according to three phases feeding program (starter, grower and finisher) during 70 days experimental period. Sasso chicks were fed ad-libitum on the respective diets and given free access to fresh water throughout the experimental period. The physical and chemical composition and energy values of the feed ingredients and experimental diets are presented in Table $(2 \& 3)$.

Table 2: Chemical composition and metabolizable energy values of the feed ingredients.

\begin{tabular}{|c|c|c|c|c|c|c|c|}
\hline \multirow[b]{2}{*}{ Feed Ingredients } & \multicolumn{6}{|c|}{$\begin{array}{c}\%) \text { Chemical composition } \\
\text { As fed basis } \\
\end{array}$} & \multirow{2}{*}{$\begin{array}{c}{ }^{*} \mathrm{ME} \\
\text { (kcal/kg diet) }\end{array}$} \\
\hline & DM & $\mathbf{C P}$ & EE & $\mathbf{C F}$ & NFE & Ash & \\
\hline Yellow corn, ground & 87.71 & 8.60 & 3.70 & 2.11 & 72.00 & 1.30 & 3350 \\
\hline Soybean meal & 89.75 & 44.60 & 1.90 & 6.55 & 32.00 & 4.70 & 2230 \\
\hline Sunflower oil & 99.00 & --- & 99.00 & --- & --- & --- & 9000 \\
\hline Corn gluten meal & 90.00 & 60.80 & 2.40 & 1.40 & 24.40 & 1.90 & 3720 \\
\hline
\end{tabular}

* ME= Metabolizable energy cited by NRC (1994).

Table 3: Composition and energy value of the basal control diets.

\begin{tabular}{|c|c|c|c|}
\hline Items & Starter & Grower & Finisher \\
\hline \multicolumn{4}{|c|}{ Physical composition (\%) } \\
\hline Yellow corn, ground & 56.03 & 62.10 & 66.60 \\
\hline Soybean meal & 34.53 & 28.28 & 24.17 \\
\hline Sunflower oil & 2.70 & 2.93 & 3.72 \\
\hline Corn gluten meal & 2.83 & 3.29 & 2.48 \\
\hline $\begin{array}{l}\text { Mono calcium } \\
\text { phosphate }\end{array}$ & 1.45 & 1.06 & 0.87 \\
\hline Limestone, ground & 1.72 & 1.66 & 1.52 \\
\hline Common salt & 0.3 & 0.3 & 0.3 \\
\hline Methionine & 0.14 & 0.04 & 0.01 \\
\hline Premix & 0.3 & 0.3 & 0.3 \\
\hline \multicolumn{4}{|c|}{ Chemical composition (\%) } \\
\hline Crude protein & 22 & 20 & 18 \\
\hline Ether extract & 5.47 & 5.82 & 6.70 \\
\hline Crude fiber & 3.48 & 3.21 & 3.02 \\
\hline Calcium & 1.0 & 0.90 & 0.80 \\
\hline available Phosphorus & 0.45 & 0.35 & 0.30 \\
\hline Lysine & 1.10 & 1.00 & 0.85 \\
\hline Methionine & 0.50 & 0.38 & 0.32 \\
\hline \multicolumn{4}{|l|}{ Energy value: } \\
\hline $\mathrm{ME}$ (kcal/kg diet) & 3000 & 3100 & 3200 \\
\hline
\end{tabular}

* Each 1.5 kg contains: Vit. A, 12000000 IU; Vit. D3, 4000000 IU; Vit. E, 50000 mg; Vit. k3, 4000 mg; Vit. B1, 5000 mg; Vit.B2, 8000 mg; Vit. B6, 5000 mg; Vit. B12, 35 mg; Vit. C, 450 mg; Niacin, 70000 mg; Methionine, 3000 mg; Pantothenic acid , $20000 \mathrm{mg}$; Folic acid $1000 \mathrm{mg}$; Biotin, $250 \mathrm{mg}$; Magnésium, $100000 \mathrm{mg}$; Copper, $15000 \mathrm{mg}$; Iron, $50000 \mathrm{mg}$; Zinc, $50000 \mathrm{mg}$; Cobalt, $250 \mathrm{mg}$; iodine $1500 \mathrm{mg}$ and selenium $250 \mathrm{mg}$.

Growth performance parameters:

Live body weight of birds was individually recorded at the beginning of experiment and then weekly throughout the 10 weeks of the experimental period. Individual LBW was totalized and divided by the number of broilers to obtain the average LBW. Body 
weight gain of broilers for each week was calculated by subtracting the LBW at the beginning of each week from that at the end of the same week. The amount of feed intake was weekly recorded in each of the different experimental groups and replicates. Average amount consumed by each bird was calculated by dividing the weekly consumed feed by its respective number of birds in each replicate and group at this week. FCR was calculated weekly as $\mathrm{kg}$ feed intake / $\mathrm{kg}$ of body weight gain.

\section{Carcass traits:}

At the end of the experiment, three birds from each group one from each replicate were slaughtered after fasting overnight, processed and the weight of dressed carcass (the weight of slaughtered birds after removal of feathers, head and feet but including all the edible offal's), liver, gizzard and heart were recorded. The weights of immune organs (bursa, spleen and thymus) were also recorded. Internal and immune organ weights were expressed as relative weight to pre-slaughter weight.

\section{Blood sampling, hematological and serum Biochemical parameters:}

Three blood samples were collected from the three slaughtered birds of each group in non-heparinized tubes. Serum was separated by centrifugation at $3000 \mathrm{rpm}$ for 10 minutes and stored at $-18^{\circ} \mathrm{C}$ till further analysis. Serum samples were assayed for estimation of total protein and its fractions (albumin and globulin), triglycerides, cholesterol,
Malondialdehyde (MDA) and catalase enzyme by spectrophotometer using commercial test kits (Spectrum, Cairo, Egypt). Another three blood samples for hematological parameters were collected into well-labeled and sterilized bottles containing ethylene diamine tetra acetic acid (EDTA) as anticoagulant. The samples were analyzed for the hematological parameters including white blood cell count (WBC) and differential leucocyte count according to (Schalm et al., 1975).

\section{Statistical analysis:}

The results were expressed as the mean \pm SE. All data were analyzed using one way analysis of variances (ANOVA) followed by LSD test using SPSS 16.0 statistical software (SPSS, Inc, Chicago, IL, 2001), www.spss.com.

\section{RESULTS}

Growth performance measurements of broilers including body weight gains, feed consumption and feed conversion ratio during feeding intervals and whole experimental period are shown in Table, 4. Carcass traits including hot carcass $\%$, eviscerated carcass $\%$, dressing carcass $\%$ and percentages of some internal and immune organs are presented in Table, 5. Effect of olive leaves powder and chamomile flower powder addition to broiler diets on serum biochemical parameters and hematological parameters are tabulated in Tables $6 \& 7$.

Table 4: Growth performance of Sasso broilers during different experimental period intervals.

\begin{tabular}{|c|c|c|c|c|c|c|}
\hline Weeks Group & 1 & 2 & 3 & 4 & 5 & 6 \\
\hline \multicolumn{7}{|l|}{ 0-3 week: } \\
\hline BWG & $202.25 \pm 4.83$ & $210.33 \pm 8.94$ & $220.33 \pm 13.32$ & $215.5 \pm 8.02$ & $200.75 \pm 6.73$ & $209.25 \pm 6.67$ \\
\hline Feed intake & $240.0 \pm 7.81$ & $237.0 \pm 5.23$ & $245.0 \pm 7.81$ & $244.0 \pm 7.81$ & $241.0 \pm 7.81$ & $252.0 \pm 7.23$ \\
\hline $\begin{array}{l}\text { Feed } \\
\text { conversion }\end{array}$ & $1.19 \pm 0.03$ & $1.13 \pm 0.05$ & $1.11 \pm 0.06$ & $1.13 \pm 0.04$ & $1.20 \pm 0.04$ & $1.20 \pm 0.03$ \\
\hline \multicolumn{7}{|l|}{ 3-6 weeks: } \\
\hline BWG & $345.83 \pm 16.06^{\mathrm{c}}$ & $375.42 \pm 12.00^{\mathrm{b}}$ & $434.58 \pm 14.11^{\mathrm{a}}$ & $359.17 \pm 16.15^{\mathrm{bc}}$ & $331.67 \pm 15.24^{\mathrm{c}}$ & $381.25 \pm 15.08^{\mathrm{ab}}$ \\
\hline Feed intake & $808.0 \pm 11.29$ & $823.3 \pm 11.28$ & $811.3 \pm 11.06$ & $802.3 \pm 11.23$ & $726.3 \pm 11.28$ & $730.0 \pm 11.01$ \\
\hline $\begin{array}{l}\text { Feed } \\
\text { conversion }\end{array}$ & $2.34 \pm 0.11^{\mathrm{ab}}$ & $2.33 \pm 0.08^{\mathrm{ab}}$ & $1.87 \pm 0.06^{\mathrm{c}}$ & $2.23 \pm 0.13^{\mathrm{a}}$ & $2.19 \pm 0.09^{b c}$ & $1.91 \pm 0.09^{c}$ \\
\hline \multicolumn{7}{|l|}{ 6-10 weeks: } \\
\hline BWG & $673.42 \pm 30.01^{\mathrm{b}}$ & $691.92 \pm 18.24^{\mathrm{ab}}$ & $720.83 \pm 23.41^{\mathrm{a}}$ & $702.50 \pm 29.27^{\mathrm{a}}$ & $688.33 \pm 22.33^{c}$ & $78.75 \pm 20.45^{\mathrm{ab}}$ \\
\hline Feed intake & $1706.0 \pm 11.90$ & $1715.3 \pm 11.97$ & $1738.3 \pm 11.89$ & $1719.0 \pm 11.92$ & $1760.3 \pm 12.03$ & $1695.0 \pm 11.90$ \\
\hline $\begin{array}{l}\text { Feed } \\
\text { conversion }\end{array}$ & $2.53 \pm 0.13^{b}$ & $2.48 \pm 0.07^{\mathrm{bc}}$ & $2.41 \pm 0.08^{c}$ & $2.45 \pm 0.11^{\mathrm{bc}}$ & $2.56 \pm 0.17^{\mathrm{a}}$ & $2.50 \pm 0.07^{\mathrm{b}}$ \\
\hline \multicolumn{7}{|l|}{ 0-10 weeks: } \\
\hline BWG & $1221.50 \pm 47.29^{c}$ & $1277.67 \pm 33.42^{\mathrm{ab}}$ & $1375.75 \pm 46.07^{\mathrm{a}}$ & $1277.17 \pm 50.30^{\mathrm{ab}}$ & $1220.75 \pm 38.85^{\mathrm{c}}$ & $1267.25 \pm 37.12^{\mathrm{ab}}$ \\
\hline Feed intake & $2754.7 \pm 7.88$ & $2775.0 \pm 4.09$ & $2794.0 \pm 7.88$ & $2765.0 \pm 7.88$ & $2727.0 \pm 7.88$ & $2677.0 \pm 20.10$ \\
\hline $\begin{array}{l}\text { Feed } \\
\text { conversion }\end{array}$ & $2.26 \pm 0.09^{\mathrm{a}}$ & $2.17 \pm 0.21^{\mathrm{b}}$ & $2.03 \pm 0.07^{\mathrm{c}}$ & $2.17 \pm 0.09^{\mathrm{b}}$ & $2.23 \pm 0.10^{\mathrm{a}}$ & $2.11 \pm 0.06^{\mathrm{ab}}$ \\
\hline
\end{tabular}

* Figures in the same row having the same superscripts are not significantly different $(\mathrm{P}<0.05)$ 
Table 5: Carcass trait and organ weights of broilers fed different experimental diets.

\begin{tabular}{|c|c|c|c|c|c|c|}
\hline Group & 1 & 2 & 3 & 4 & 5 & 6 \\
\hline $\begin{array}{l}\text { Pre-slaughter } \\
\text { Wt.(g) }\end{array}$ & $1121.7 \pm 57.0$ & $1155.00 \pm 37.53$ & $1215.00 \pm 59.23$ & $1158.33 \pm 95.28$ & $1135.00 \pm 50.08$ & $1208.33 \pm 25.22$ \\
\hline $\begin{array}{l}\text { Hot carcass } \\
(\%)\end{array}$ & $79.88 \pm 1.08$ & $81.05 \pm 0.74$ & $80.43 \pm 0.49$ & $79.89 \pm 0.37$ & $80.22 \pm 0.86$ & $80.81 \pm 0.54$ \\
\hline $\begin{array}{l}\text { Eviscerated } \\
\text { carcass\% }\end{array}$ & $64.88 \pm 2.42$ & $62.82 \pm 1.48$ & $62.90 \pm 1.15$ & $62.43 \pm 1.47$ & $62.57 \pm 0.20$ & $64.14 \pm 0.75$ \\
\hline $\begin{array}{l}\text { Dressed } \\
\text { carcass \% }\end{array}$ & $70.22 \pm 3.12$ & $68.34 \pm 1.16$ & $67.47 \pm 0.95$ & $67.80 \pm 0.97$ & $67.94 \pm 0.51$ & $68.98 \pm 0.82$ \\
\hline Liver \% & $2.29 \pm 0.24$ & $2.16 \pm 0.12$ & $2.45 \pm 0.15$ & $2.26 \pm 0.25$ & $2.13 \pm 0.13$ & $1.97 \pm 0.07$ \\
\hline Heart \% & $0.61 \pm 0.03$ & $0.62 \pm 0.06$ & $0.56 \pm 0.04$ & $0.55 \pm 0.04$ & $0.63 \pm 0.09$ & $0.59 \pm 0.07$ \\
\hline Gizzard\% & $2.26 \pm 0.02^{\mathrm{ab}}$ & $2.62 \pm 0.21^{\mathrm{a}}$ & $2.50 \pm 0.29^{\mathrm{ab}}$ & $1.87 \pm 0.13^{\mathrm{b}}$ & $2.44 \pm 0.15^{\mathrm{ab}}$ & $2.49 \pm 0.41^{\mathrm{ab}}$ \\
\hline thymus \% & $0.56 \pm 0.051^{\mathrm{bc}}$ & $0.68 \pm 0.09^{\mathrm{ab}}$ & $0.74 \pm 0.12^{\mathrm{a}}$ & $0.60 \pm 0.05^{\mathrm{b}}$ & $0.82 \pm 0.12^{\mathrm{a}}$ & $0.51 \pm 0.18^{c}$ \\
\hline Spleen \% & $0.29 \pm 0.06^{\mathrm{ab}}$ & $0.21 \pm 0.01^{\mathrm{c}}$ & $0.23 \pm 0.01^{\mathrm{c}}$ & $0.29 \pm 0.06^{\mathrm{ab}}$ & $0.32 \pm 0.06^{\mathrm{a}}$ & $0.30 \pm 0.03^{\mathrm{a}}$ \\
\hline Bursa \% & $0.03 \pm 0.09^{\mathrm{c}}$ & $0.15 \pm 0.0^{\mathrm{b}}$ & $0.26 \pm 0.08^{\mathrm{a}}$ & $0.18 \pm 0.07^{\mathrm{ab}}$ & $0.16 \pm 0.05^{\mathrm{ab}}$ & $0.15 \pm 0.01^{\mathrm{b}}$ \\
\hline
\end{tabular}

* Figures in the same row having the same superscripts are not significantly different $(\mathrm{P}<0.05)$

Table 6: Serum biochemical parameters of broilers fed different experimental diets.

\begin{tabular}{|c|c|c|c|c|c|c|}
\hline Group & 1 & 2 & 3 & 4 & 5 & 6 \\
\hline $\begin{array}{l}\text { Total protein } \\
\text { (g/dl) }\end{array}$ & $4.03 \pm 0.01^{\mathrm{c}}$ & $4.13 \pm 0.01^{\mathrm{bc}}$ & $4.99 \pm 0.05^{\mathrm{ab}}$ & $3.94 \pm 0.02^{\mathrm{c}}$ & $4.24 \pm 0.03^{b c}$ & $4.11 \pm 0.03^{\mathrm{bc}}$ \\
\hline $\operatorname{Albumin}(\mathrm{g} / \mathrm{dl})$ & $1.37 \pm 0.25$ & $1.53 \pm 0.27$ & $1.28 \pm 0.13$ & $1.54 \pm 0.15$ & $1.40 \pm 0.17$ & $1.54 \pm 0.21$ \\
\hline Globulin (g/dl) & $2.66 \pm 0.27^{\mathrm{bc}}$ & $2.60 \pm 0.29^{\mathrm{bc}}$ & $3.70 \pm 0.18^{\mathrm{ab}}$ & $2.40 \pm 0.17^{\mathrm{bc}}$ & $2.84 \pm 0.20^{\mathrm{bc}}$ & $2.57 \pm 0.22^{\mathrm{bc}}$ \\
\hline Alb/Glob ratio & $0.55 \pm 0.15^{\mathrm{ab}}$ & $0.63 \pm 0.18^{\mathrm{ab}}$ & $0.35 \pm 0.05^{b}$ & $0.66 \pm 0.11^{\mathrm{ab}}$ & $0.51 \pm 0.10^{\mathrm{ab}}$ & $0.62 \pm 0.13^{\mathrm{ab}}$ \\
\hline $\begin{array}{l}\text { Cholesterol } \\
\text { (mg/dl) }\end{array}$ & $167.32 \pm 2.38^{\mathrm{a}}$ & $105.59 \pm 2.90^{c}$ & $132.93 \pm 1.11^{\mathrm{b}}$ & $144.07 \pm 0.62^{\mathrm{ab}}$ & $136.86 \pm 0.49^{b}$ & $112.24 \pm 1.18^{\mathrm{bc}}$ \\
\hline $\begin{array}{l}\text { Triglyceride } \\
\text { (mg/dl) }\end{array}$ & $68.53 \pm 0.42^{\mathrm{a}}$ & $60.38 \pm 0.63^{\mathrm{ab}}$ & $62.47 \pm 0.27^{\mathrm{ab}}$ & $65.13 \pm 0.42^{\mathrm{a}}$ & $63.41 \pm 0.03^{\mathrm{ab}}$ & $55.64 \pm 0.54^{\mathrm{b}}$ \\
\hline MDA $(\mu \mathrm{mol} / \mathrm{ml})$ & $7.72 \pm 0.07^{\mathrm{a}}$ & $6.43 \pm 0.07^{\mathrm{bc}}$ & $6.38 \pm 0.05^{\mathrm{b}}$ & $5.66 \pm 0.03^{\mathrm{c}}$ & $6.73 \pm 0.01^{\mathrm{ab}}$ & $8.57 \pm 0.85^{\mathrm{a}}$ \\
\hline Catalase enzyme & $157.13 \pm 8.24^{b c}$ & $135 \pm 0.82^{\mathrm{bc}}$ & $248.73 \pm 4.14^{\mathrm{a}}$ & $278.74 \pm 1.25^{\mathrm{a}}$ & $255.69 \pm 0.81^{b}$ & $240.57 \pm 4.11^{\mathrm{bc}}$ \\
\hline
\end{tabular}

* Figures in the same row having the same superscripts are not significantly different $(\mathrm{P}<0.05)$. 
Table 7: Differential leucocytic cell of broilers fed different experimental diets.

\begin{tabular}{lcccccc}
\hline & $\mathbf{1}$ & $\mathbf{2}$ & $\mathbf{3}$ & $\mathbf{4}$ & $\mathbf{5}$ & $\mathbf{8}$ \\
\hline $\begin{array}{l}\text { Group } \\
\text { parameters }\end{array}$ & & & & & & \\
\hline $\mathbf{1 0 3 / m m 3 )}$ & $14.67 \pm 1.13^{\mathrm{c}}$ & $16.67 \pm 0.93^{\mathrm{b}}$ & $14.33 \pm 1.20^{\mathrm{c}}$ & $19.55 \pm 0.03^{\mathrm{a}}$ & $16.10 \pm 0.06^{\mathrm{b}}$ & $19.95 \pm 0.84^{\mathrm{a}}$ \\
\hline Lymphocytes \% & $75.00 \pm 2.89^{\mathrm{b}}$ & $88.33 \pm 1.67^{\mathrm{a}}$ & $75.00 \pm 2.89^{\mathrm{b}}$ & $89.00 \pm 3.46^{\mathrm{a}}$ & $86.50 \pm 3.18^{\mathrm{a}}$ & $91.00 \pm 1.73^{\mathrm{a}}$ \\
\hline Segment \% & $17.50 \pm 1.44$ & $18.50 \pm 0.29$ & $23.50 \pm 0.29$ & $15.00 \pm 0.58$ & $13.50 \pm 0.2$ & $7.50 \pm 1.44$ \\
\hline Eosinophils \% & $1.00 \pm 0.58$ & $1.00 \pm 0.30$ & $0.5 \pm 0.32$ & $0.5 \pm 0.31$ & $0.30 \pm 0.29$ & $0.33 \pm 0.30$ \\
\hline Monocytes \% & $1.00 \pm 0.58$ & $1.00 \pm 0.29$ & $0.5 \pm 0.58$ & $1.33 \pm 0.33$ & $1.00 \pm 0.33$ & $1.50 \pm 0.29$ \\
\hline
\end{tabular}

* Figures in the same row having the same superscripts are not significantly different $(\mathrm{P}<0.05)$

\section{DISCUSSION}

\section{Growth performance:}

There were a significant differences $(\mathrm{p}<0.05)$ in the body weight gains and feed conversion ratios between the different experimental groups and control as shown in Table 4. At the end of the experimental period, olive leaves powder supplemented groups (groups 2\&3) and $0.75 \%$ chamomile flowers powder supplemented group (group 4) and birds in the sixth group fed on a combination of olive leavers powder and chamomile flowers powder recorded higher body weight gain $(1277.67 \pm 33.42 \mathrm{~g}, \quad 1375.75 \pm 46.07 \mathrm{~g}, \quad 1277.17 \pm 50.30$ and $1267.25 \pm 37.12 \mathrm{~g}$ ) and best feed conversion $(2.17,2.03,2.17$ and 2.11$)$, respectively compared to control group $(1221.50 \pm 47.29 \mathrm{~g} \& 2.26)$. The highest body weight gain and best feed conversion ratio were recorded in the third group fed on diet supplemented with $2.0 \%$ olive leaves powder (1375.7g \& 2.03), while the lowest values were recorded in the control group. Similar results were obtained by Bouaziz et al. (2008), El-damarawy et al. (2013), Bahsi et al. (2016), Ait-Kaki et al. (2018) and Nafea \& Hussein (2018) who reported that, the addition of olive leaves powder to broiler diets at level of 20 or $25 \mathrm{~g} / \mathrm{kg}$ diet resulted in a significant increase in the body weight gain and improved feed conversion. Current results also supported by the findings of Al-kaisse \& khalel (2011) and Ibrahim et al. (2018) who found that the addition of chamomile flowers powder at level of $0.75 \%$ to broiler diets increased significantly body weight gain and improved feed conversion. Abaza et al. (2003) stated that addition of $0.25 \%$ chamomile flowers to broiler diets improved body weight gain. The benefits of dietary olive leaves are possibly due to the presence of polyphenols and particularly oleuropein, the main active component in this material (Malik \& Brandford, 2008). Olive leaves powder contain phenolic compounds that have a structure and function similar to the steroid hormones. Steroid hormones and phenolic compounds increase the basic metabolic rate and have a role in improving the digestibility of feeds, thus increasing the utilization of nutrients in the diet (Guinda et al., 2004). Chamomile flowers powder have endocrine stimulating effect via enhancement of thyroxin hormone activity with consequence acceleration of nutrients metabolites resulted in an increasing body weight (AL-Hamo et al., 2003). In addition, anti-inflammatory, antimicrobial, antioxidant and antifungal effects of chamomile flowers that attributed to presence of some essential compounds resulted in improvement of body weight gain (Santurio et al., 2007). On the other hand, Govaris et al. (2010), Shafey et al. (2013), Sarica \& Toptas (2014) and Ait-Kaki et al. (2018) found that, dietary supplementation of olive leaves powder had no significant effect on body weight gain and feed conversion ratio. No significant differences were observed in body weight gain of broilers fed diet supplemented with $1.0 \%$ chamomile flowers powder (Ahmed et al., 2015). Al-kaisse \& khalel (2011) and Mahmoud (2013) reported that, adding of chamomile flowers at the levels of $1 \%$ increased body weight gain significantly. Jakubcova et al. (2014) found that, the addition of chamomile extract to the broiler diets at the levels of $(0.3$ and 0.6$) \%$ had no significant effect on body weight gain, while birds fed on diet supplemented with $1 \%$ chamomile flower recorded lower body weight gain which might be attributed to the anti-nutritional components of chamomile like tannin. Tanin leads to lack of sufficient nutritional absorption in the intestine. On the contrary, Al-kaisse \& khalel (2011) and Mahmoud (2013) reported that adding of chamomile flowers at the levels of $1 \%$ increased body weight gain significantly. On the other hand, Ahmed et al. (2015) found no significant differences were observed in body weight gain of broilers fed diet supplemented with $10 \mathrm{~g} / \mathrm{kg}$ chamomile flowers. 
Addition of olive powder and chamomile flowers powder single or in combination had no significant effect on feed intake of Sasso broilers during feeding intervals or whole experimental period compared with control as shown in Table 4. Similar results were recorded by El-damarawy et al. (2013), Shafey et al. (2013), Sarica \& Toptas (2014), Cayan and Erener (2015), Rezar et al. (2015) and Ait-Kaki et al. (2018) who reported that olive leaves powder had no significant effect on feed intake. On the contrary Al-kaisse \& khalel (2011) found that adding of chamomile flowers at the levels of $1 \%$ decrease feed intake significantly, while, Nafea \& Hussein (2018) showed that, adding olive leaves at the levels of 5 and $10 \mathrm{~g} / \mathrm{kg}$ diet significantly increase feed intake.

\section{Carcass traits:}

The inclusion of olive leaves powder and chamomile flowers powder into the sasso broilers diets did not affect significantly on the hot carcass \%, eviscerated carcass $\%$, dressing\% and relative weights of liver, gizzard and heart (Table 5). Similar results were obtained by Shafey et al. (2013) and Ait-Kaki et al. (2018) who found that, adding different levels of olive leaves did not have any significant effect on eviscerated carcass and edible offal weights. Sarica and Toptas (2014) reported that, oleuropein supplementation at the levels of 50,100, 150 and $200 \mathrm{mg} / \mathrm{kg}$ had not affect on the relative weights of some digestive organs. Al-kaisse \& khalel (2011), Mahmoud (2013), Jakubcova et al. (2014) and Ahmed et al. (2015) observed that, the addition of different levels of chamomile flowers had no significant effect on relative weight of internal organs. On the contrary, Ibrahim et al. (2018) reported that, adding chamomile flowers at the levels of $0.75 \%$ to ducks diet increased carcass weight, gizzard weight and giblet weights. Eldamarawy et al. (2013) found that, chicks fed on diet supplemented with $2 \%$ olive leaves decreased significantly the relative weight of liver compared with control one.

\section{Serum biochemical parameters:}

Serum biochemical values revealed a significant differences $(\mathrm{p}<0.05)$ among the experimental groups as shown in Table 6. Total serum protein and globulin were significantly increased, while albumin/globulin ratio were significantly decreased in the third group compared to control one. These results are in harmony with the findings of Eldamarawy et al. (2013) and Nafea \& Hussein (2018) who reported that, chicks fed on diet supplemented with $2 \%$ olive leaves had significant increase in serum protein and globulin levels. On the other hand, Ait-Kaki et al. (2018) stated that, adding different levels of olive leaves did not affect significantly on total serum protein level of broilers. Ahmed et al. (2015) showed that, no significant differences were observed in total protein levels in broilers fed on diet supplemented with $10 \mathrm{~g} / \mathrm{kg}$ chamomile flowers. Ibrahim et al. (2018) reported that, adding chamomile flowers at the levels of 0.50 , $0.75 \%$ to ducks diet significantly increase globulin, albumin and total protein levels. Results also indicated that, there was a significant decrease in serum cholesterol levels in all treatment groups except fourth group, while there was significantly decrease in triglycerides level in sixth group in comparison with control. Hypercholesterolemia may be due to the inhibition of dietary cholesterol absorption in the intestine or its production by liver or stimulation of the biliary secretion of cholesterol and cholesterol excretion in the feces (Jemai et al., 2008). Similar effects were recorded by Eldamarawy et al. (2013) and Nafea \& Hussein (2018) who reported that, serum cholesterol and triglycerides levels of birds fed on diet supplemented with olive leaves were significant decreased in comparison with control one. Also, Ahmed et al. (2015) showed that, a significant decrease in serum cholesterol and triglycerides levels were observed in broilers diet supplemented with $10 \mathrm{~g} / \mathrm{kg}$ chamomile flowers. On the other hand, Ait-Kaki et al. (2018) stated that adding different levels of olive leaves to broiler diets did not have any significant effect on triglycerides levels.

\section{Oxidative status and immune response.}

Serum levels of malondialdhyde (MDA) were significantly decreased in the second, third and fourth groups while no significant differences were observed in the fifth and sixth groups as shown in Table 6. Serum catalase enzyme was significantly increased in the third and fourth groups compared with other treated groups and control. These results are in harmony with the findings of Ahmed et al. (2017) and Oke et al. (2017) who found that, adding different levels of olive leaves powder to broiler diets significantly decreased malondialdhyde (MDA) concentration. Ahmed et al. (2015) stated that, diets supplemented with $10 \mathrm{~g}$ basil, $10 \mathrm{~g}$ chamomile and $5 \mathrm{~g}$ basil plus $5 \mathrm{~g}$ chamomile per $\mathrm{kg}$ significantly decreased the serum level of malondialdehyde, whereas the activities of catalase was significantly increased $(\mathrm{P}<0.05)$. The antioxidant effects of olive leaves are related to phenolic compounds which considered free radical scavenger by breaking the free radical chain reaction (Lee \& Lee, 2010 and Hayes et al., 2011). Silva et al. (2006) and Jemai et al. (2008) reported that, olive leaves or olive leaves extract are a source of many phytochemicals which considered as potential sources of antioxidant.

The effect of olive leaves and chamomile flowers supplementation on immune response of Sasso broilers are presented in Table 7. WBCs counts and lymphocytes \% were significantly increased in all treated groups except third group fed on 2\% OLP. Obtained results indicated that, there were no 
significant differences in segment $\%$, Eosinophils \% and Monocytes \% between all treated groups. Concerning the weights of immune organs, there were significantly increased in thymus weight in the third and fifth groups, while the weight of spleen significantly increased in the fifth and sixth groups in comparison with control. The weights of bursa were significantly increased in all treated groups compared with control as shown in Table 5. These results are in agreement with the findings reported by El-Damarawy et al. (2013), Parasei (2014) and Ahmed et al. (2017) who found that, white blood cells counts, lymphocytes $\%$ and the relative weights of bursa and spleen were significantly $(\mathrm{p}<0.01)$ increased in broiler fed on diet supplemented with oleuropein. Dada et al. (2015) reported that, addition of chamomile powder at levels of $4 \mathrm{~g} / \mathrm{kg}$ were significantly increased percentage of bursa of fabercius weight $(\mathrm{P}<0.05)$. Opposite results were obtained by Oke et al. (2017) who found that, chicks fed diets supplemented with olive leaves powder had no significant effect on white blood cells (WBC) and lymphocyte. Al-Kaisse \& Khalel (2011) stated that, addition of $0.25,0.50,0.75$ and $1 \%$ of chamomile flowers powder to broiler diets had no effect WBC count. The relative weights of spleen and bursa were significantly not affected by addition of basil and chamomile to broiler diets (Ahmed et al., 2015). Herbs may influence immune system via four mechanisms including activation of phagocytic property, stimulation of fibroblasts, increscent of respiratory activity and leukocyte movement which influence gastrointestinal mucosal lymphocyte and also stimulate local immunity (Bauer et al., 1989).

\section{CONCLUSION}

The results of the current study concluded that the best growth performance and immune response were observed in broilers of the third group fed diet containing $2 \%$ olive leaves powder.

\section{REFERENCES}

Abaza, I.M.; Asar, M.A.; EL-Shaarrawi, G.E. and Hassan, M.F. (2003): Effect of using Nigella seed, Chamomile flowers, Theme flowers and Harmala seed as feed additives on performance of broiler. Egyptian Journal Agriculture Research, 81: 735-749.

Ahmed, H.A.; Sadek, K.M. and Taha, A.E. (2015): Impact of two herbal seeds supplementation on growth performance and some biochemical blood and tissue parameters of broiler chickens. International Journal of Agricultural Technology 9 (3): 255-60.

Ahmed, M.M.; El-Saadany, A.S.; Shreif, E.Y. and ElBarbary, A.M. (2017): Effect of dietary olive leaves extract (oleuropein) supplementation on productive, physiological and immunological parameters in Bandarah chickens during production period. Egyptian Poultry Science Journal, 37 (1): 277-292.

Ait-Kaki, A.; Diaw, M.T.; Geda, F. and Moula, N. (2018): Effects of Artemisia herba-alba or olive leaf (Olea europaea) powder supplementation on growth performance, carcass yield and blood biochemical parameters in broilers. Veterinary World, 11 (11): 1624-1629

Al Bahtiti, N.H. (2012): Chemical Analysis and Biological Activity of Jordanian Chamomile Extracts.Advance Journal of Food Science and Technology, 4 (1): 22-25.

AL-Hamo, R.N. (2003): The inhabiting effect of some plant extracts on primary heads as examine in vitro-College of Veterinary Medicine-Mosul University, symposium about chamomile that hold a meeting in College of Pharmacology.Mosul University 1-3 march (Abstr) (in Arbic).

Al-Kaisse, G.A. and Khalel, E.K. (2011): The potency of chamomile flowers (Matericaria chamomilla L.) as feed supplements (growth promoters) on productive performance and hematological parameters constituents of broiler. International journal of poultry science, 10 (9): 726-729.

AOAC (Assocition of Official Analytical Chemists) (1990): Official Methods of Analysis (14thEd.), Washington, DC.

Bahsi, M.; Çiftci, M.; Şimsek, Ü.G.; Azman, M.A.; Özdemir, G.; Yilmaz, $\ddot{O}$. and Dalkilic, $B$. (2016): Effects of olive leaf extract (oleuropein) on performance, fatty acid levels of breast muscle and some blood parameters in Japanese quail (Coturnix coturnix Japonica) reared in different stocking densities. Ankara Üniversitesi Veteriner Fakültesi Dergisi, 63 (1): 61-68.

Bauer, R. and Reminger, P (1989): TLC and HPLC analysis of alkamides in Echinacea drugs. Journal of Medicinal Plant, 55: 367-371.

Bisignano, G.; Lagana, M.G.; Trombetta, D.; Arena, S.; Nostro, A; Uccella, N.; Mazzanti, G. and Saija, A. (2001): In vitro antibacterial activity of some aliphatic aldehydes from Oleaeuropaea L. FEMS Microbiology Letters, 198: 9-13

Botsoglou, E.; Govaris, A.; Christaki, E. and Botsoglou, N. (2010): Effect of dietary olive leaves and/or $\alpha$-tocopheryl acetate supplementation on microbial growth and lipid oxidation of turkey breast fillets during refrigerated storage. Food Chemistry, 121: 17-22.

Bouaziz, M.; Hammami, H.; Bouallagui, Z.; Jemai, H. and Sayadi, S. (2008): Production of antioxidants from olive processing byproducts. Electronic Journal of Environmental, Agricultural and Food 
Chemistry, 7 (8): 3231-3236.

Cayan, H. and Erener, G. (2015): Effect of olive leaf (Olea europaea) powder on laying hens performance, egg quality and egg yolk cholesterol levels. Asian Australas Journal Animal Science, 28:538-543.

Dada, R.; Toghyani, M. and Tabeidian, S.A. (2015): The effect of chamomile flower (Matricaria chamomilla L.) extract and powder as growth promoter on growth performance and digestive organs of broiler chickens. Research opinions in animal and veterinary sciences, 5 (7): 290-294.

El-damrawy, S.Z. (2011): Alleviate the oxidative stress in aged rabbit bucks by using olive leave extract. Egyptian Poultry Science, 31 (4): 737-744.

El-Damrawy, S.Z.; Khalifah, M.M. and Fares, W.A. (2013): Dietary olive leaf and antioxidative status in chickens "performance, some physiological traits and immunological responses of Mandarah chicks supplemented olive leaves powder in their diets. Egyptian Poultry Science, 33 (1): 279-287.

Erener, G.; Ocak, N.; Oztürk, E.; Cankaya, S. and Özkanca, $R$. (2009): The Effects of olive leaf extract on performance, some blood parameters and cecal microflora of broilers. Food Chemistry, 93: 197-204.

Florou-Paneri, P.; Dotas, D.; Mitsopoulos, I.; Dotas, V.; Botsoglou, E.; Nikolakakis, I. and Botsoglou, N. (2006): Effect of feeding rosemary and $\alpha$-tocopheryl acetate on hen performance and egg quality. Japan Poultry Science, 43:143-149.

Fredrickson, W.R.F. and Group, S. Inc. (2000): Method and Composition for Antiviral Therapy with Olive Leaves.United States Patent, 6: 117- 884.

Galib, A.M.A. and Khalel, E.K. (2011): The potency of chamomile flowers (matericaria chamomilla L.) asfeed supplements (growth promoters) on productive performance and hematologicalparameters constituents of broilers. International Journal Poultry Science, 10 (9): 726-729.

Ghazalah, A.A. and Ali, A.M. (2008): Rosemary leaves as a dietary supplement for growth in broiler chickens. International Journal of Poultry Science, 7 (3): 234-239.

Govaris, A.; Botsoglou, E.; Moulas, A. and Botsoglou, N. (2010): Effect of dietary olive leaves and rosemary on microbial growth and lipid oxidation of turkey breast during refrigerated storage. South African Journal of Animal Science, 40 (2): 145-155.

Guinda, A.; Camino, M.C.P. and Lanzón, A. (2004): Supplementation of oils with oleanolic acid from the olive leaf (Olea europaea). European Journal of Lipid Science and Technology, 106 (1): 22-26.
Hamad, I. (2015): Antioxidant Activity and Potential Hepato - Protective Effect of Saudi Olive Leaf Extract. 2nd Int'l Conference on Advances in Environment, Agriculture \& Medical Sciences, 72-75.

Hayes, J.E.; Allen, P.; Brunton, N.; O’Grady, M.N. and Kerry, J.P. (2011): Phenolic composition and in vitro antioxidant capacity of four commercial phytochemical products: olive leaves extract (Olea europaeaL.) lutein, sesamol and ellagic acid. Food Chemistry, 126: 948-955.

Huyghebaert, G.; Ducatelle, R. and Van Immerseel, F. (2011): An update on alternatives to antimicrobial growth promoters for broilers. Veterinary Journal, 187 (2): 182-8.

Ibrahim, N.S.; Sabic, E.M. and Abu-Taleb, A.M. (2018): Effect of inclusion irradiated olive pulp in laying quail diets on biological performance. Journal of Radiation Research and Applied Sciences, 1687-8507.

Jakubcova, Z.U.Z.A.N.A.; Zeman, L.A.D.I.S.L.A.V.; Horky, P.A.V.E.L.; Mrkvicova, E.; Mares, P.E.T.R.; Mrazkova, E. and Stastnik, O.N.D.R.E.J. (2014): The influence of the addition of chamomile extract to the diet of chickens. MendelNet, 147-150.

Jemai, H.; Bouaziz, M.; Fki, I.; El Feki, A. and Sayadi, S. (2008): Hypolipidimic and antioxidant activities of oleuropein and its hydrolysis derivative-rich extracts from olive leaves. Chemico-Biological Interaction, 176: 88-98.

Korukluoglu, M.; Sahan, Y.; Yigit, A.; Ozer, E.T. and Gücer, S. (2010): Antibacterial activity and chemical constitutions of oleaeuropaea leaf extracts. Journal of Food Processing and Preservation, 34 (3): 383-396.

Lee-Huang, S.; Zhang, L.; Huang, P.L.; Chang, Y.T. and Huang, P.L. (2011): Anti-HIV activity of olive leaf extract (OLE) and modulation of host cell gene expression by HIV-1 infection and OLE treatment. Biochemical and Biophysical Research Communications, 307 (4): 1029-1037.

Lee, O.H. and Lee, B.Y. (2010): Antioxidant and antimicrobial activities of individual and combined phenolics in Olea europaea leaf extract. Bioresource Technology, 101: 37513754.

Mahmoud, Z.A. (2013): The effect of chamomile plant (Matricaria chamomile) as feed additives on productive performance, carcass characteristics and immunity response of broilers. International journal of poultry science, 12 (2): 111-116.

Malik, N.S.A. and Bradford, J.M. (2008): Recovery and stability of oleuropein and other phenolic compounds during extraction and processing of olive (Olea europaeaL.) leaves. Journal of Food Agriculture and Environment, 6 (2): 
8-13.

Mujić, I.; Živković, J.; Nikolić, G.; Vidović, S.; Trutić, N.; Kosić, U.; Jokić, S. and Ruznic, A. (2011): Phenolic Compounds in Olive Leaf Extract as a Source of Useful Antioxidants. Croatian Journal of Food Technology, Biotechnologyand Nutrition, 6 (3-4):129-133.

Nafea, H.H. and Mostafa, M.H. (2018): Effect of adding different levels of olive leaf powder to the diet on the production performance and some physiological characteristics of broilers. Journal of Research in Ecology, 6 (2): 21762184.

N.R.C. (1994): Nutrient Requirements of poultry, 9 threv.ed. National Academy press, Washington, C.,USA.

Oke, O.E.; Emeshili, U.K.; Iyasere, O.S.; Abioja, M.O.; Daramola, J.O.; Ladokun, A.O. and Balogun, S.I. (2017): Physiological responses and performance of broiler chickens offered olive leaf extract under a hot humid tropical climate. Journal of Applied Poultry Research, 26 (3): 376-382.

Parsaei, S.; Zahra, A. and Houchmant, M. (2014): Effect of olive leaf on blood stabilities and humoral immunity response of broiler chickens. International Journal of Advanced Biological and Biomedical research, 2:
741-751.

Rezar, V.; Levar, A. and Salobir, J. (2015): The effect of olive by products and their extracts on antioxidative status of laying hens and oxidative stability of eggs enriched with n-3 fatty acids. Poljoprivreda, 21 (1): 216-219.

Sarica, S. and Toptas, S. (2014): Effects of dietary oleuropein supplementation on growth performance, serum lipid concentrations and lipid oxidation of Japanese quails. Journal of animal physiology and animal nutrition, 98 (6): 1176-1186.

Schalm, D.W.; Jain, N.C. and Caroll, E.J. (1975): Veterinary Hematology. $3 r d$ ed. Lea and Febiger, PA. USA.

Shafey, T.M.; Heimler, D. and Pieeters, L. (2013): In vitro anti-complementary activity of flavonoids from olive (Oleaeuropaea L.) leaves. Pharmazie, 51:765-768.

Silva, S.; Gomes, L.; Leitao, F.; Coelho, A.V. and Vilas Boas, L. (2006): Phenolic compounds and antioxidant activity of Oleaeuropaea L. fruits and leaves. Food Science and Technology International, 12: 385-395.

Spss, (2001): Statistical software package for the social sciences. Spss Inc. United States of America.

\section{تأثير استخدام مسحوق أوراق الزيتون وزهرة البابونج علي كفاءة الأداء وخواص الأبيحة والاستجابة المناعية لبدارى التسمين (سلالكة الساسو).}

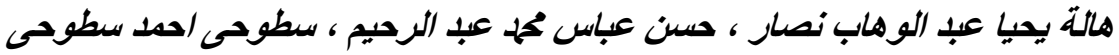

E-mail: halavet63@yahoo.com Assiut University web-site: www.aun.edu.eg

أجريت هذه الدراسة لمعرفة نأثير استخدام مسحوق اوراق الزيتون وزهرة البابونج منفردة او مجتمعة علي كفاءة الأداء وخواص

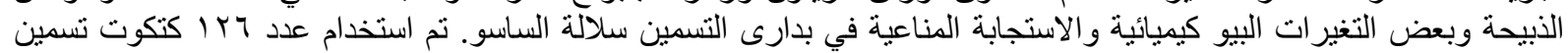

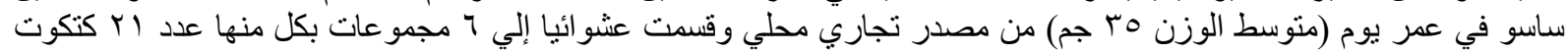

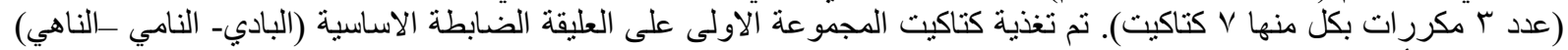

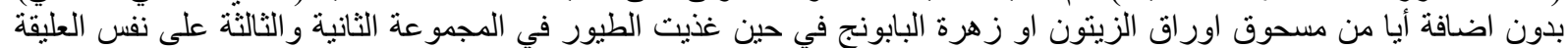

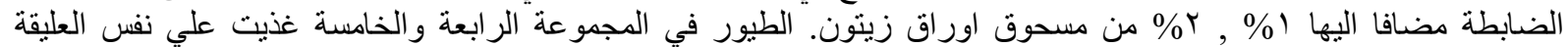

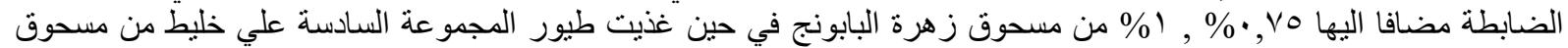

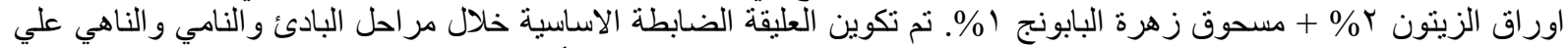

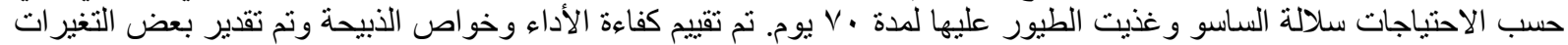

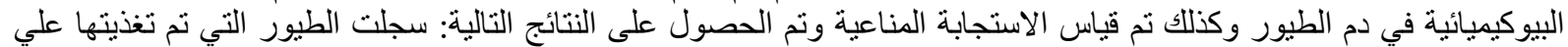

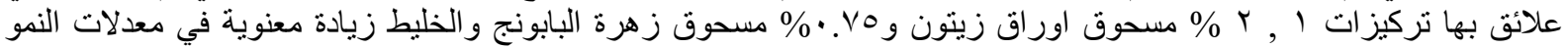

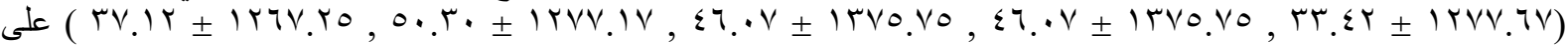

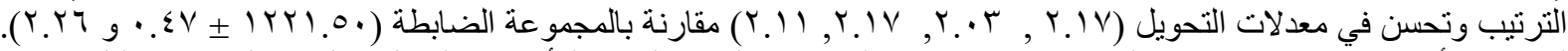

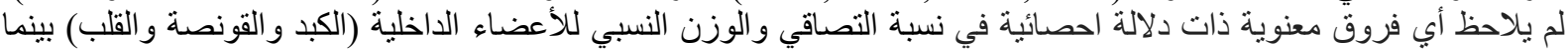

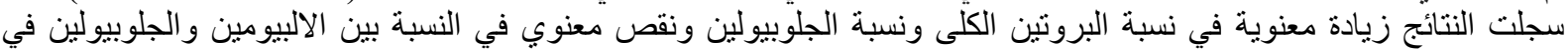

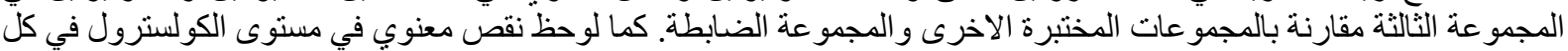

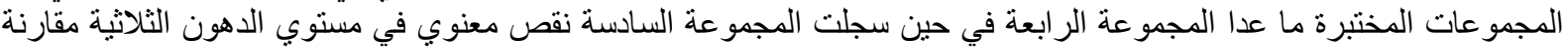

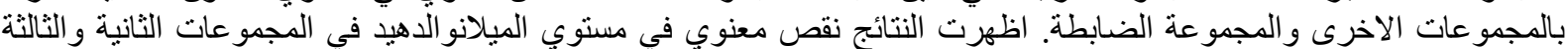

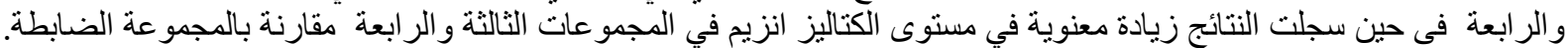

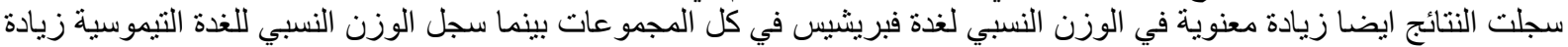

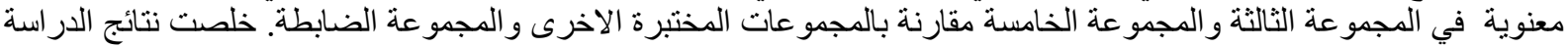

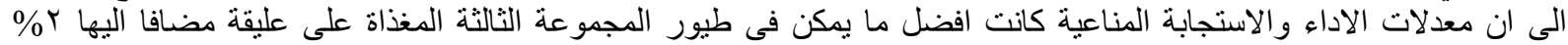

